\title{
NOTES ON IBN HAZM'S REJECTION OF ANALOGY (QIYĀS) IN MATTERS OF RELIGIOUS LAW
}

\author{
Fadel I. Abdallah*
}

\section{Introduction}

Ibn Hazm (994-1064) was no doubt one of the most outstanding intellectual figures of Muslim Spain in particular and of the whole Muslim world in general. Though it is beyond the purpose and scope of this paper to give a complete profile of the man and his place in the intellectual history of Islam, it remains necessary to make some introductory remarks that would help in understanding the topic under discussion.'

In Ibn Hazm's scholarly preparation the second stage was characterized to be a juridico-theological preparation to which he fully devoted himself following his political failure; the year 1031 is usually proposed to be the turning point in this new orientation of Ibn Hazm's intellectual life. ${ }^{2}$ It was during this second stage that he wrote profusely on a variety of subjects and distinguished himself as a master dialectician and polemicist. His major works on religious matters such as Fișal, Ihkäm, and Muhalla were the products of this period; in them as well as in many other treatises, Ibn Hazm discusses his religious ideas and doctrine and enthusiastically refutes his adversaries. "As a master dialectician he insisted on proofs (barahin), whether arrived at on the basis of the holy texts (nușüs), or through logical demonstration, or both." ${ }^{3} \mathrm{His}$ use and reliance on analysis of textual material and information was perhaps the most clear feature of Ibn Hazm's polemics; this method was always in

*Dr. Fadel 1. Abdallah is a lecturer of Arabic \& Islamic Studies, Department of South and Southwest Asian Studies, University of Minnesota, Minneapolis, USA

1 For a full discussion of the sources and works about Ibn Hazm, see Anwar Chejne, Ibn Hazm, (Kazi Publication Inc., Chicago, 1982), Chapter I, pp. 1-19.

2 Ibid., p. 36

3 Ibid., p. 46. For more details on Ibn Hazm as a dialectician, see Chejne, op. cit., Chapter III, pp. 36-45. See also Muhammad Abu Zahrah, Ibn Hazm, (Cairo, 1954), pp. 177-197 and Zakariyya Ibrahim, Ibn Hazm al-Andalusi, (Cairo, 1966), pp. 130-154. 
conformity with his Zahirite doctrine; and was largely employed in his disputation with Jews, Christians, or his co-religionist opponents. ${ }^{4}$

Since Ibn Hazm's religious ideas originated within the framework of his Zahirite doctrine, a word about this doctrine seems to be necessary as a prerequisite to understand his rejection of analogy in matters of religious law. The Zahirite doctrine was founded in the East by Däwüd ibn Khalaf (d. 883) who was a Shafi' ite before developing his new doctrine. For this reason it is believed that the Shafi' ite theology was responsible for paving the way for the appearance of the new doctrine. ${ }^{5}$ It is also believed that this new doctrine originated as a reaction to the widespread activities of those who applied analogical deduction (qiyas) to arrive at legal decisions in matters of religion. ${ }^{6}$ Then the new doctrine reached Muslim Spain and was adopted by a small number of Andalusian theologians through whom it reached Ibn Hazm who developed the new doctrine and became the most eloquent spokesman of it. The essence of the Zahirite doctrine centers around the idea that the Qur'an and the authenticated traditions ought to be the sole guiding criteria for arriving at juridico-theological decisions. They should be understood in the context of what they say rather than what they may imply. This can be done by adhering strictly to the apparent meaning (zähir) of the text and by conforming to the grammatical and lexical rules of the Arabic language. ${ }^{7}$ Hence the name of the new doctrine (al-Zähiriyyah) which emphasized the exoteric meanings of the texts as opposed to the traditional way of emphasizing the esoteric (bätin) meanings of the texts. ${ }^{8}$

Before proceeding to discuss Ibn Hazm's rejection of using analogical deduction (qiyäs) to arrive at legal decisions, a word should be said about qiyäs; its meanings, its historical background, and its position as a source for arriving at legal decisions in matters that were not directly mentioned in the Qur'an, the Prophetic traditions, and the consensus (ijma ${ }^{c}$ ) of the companions of the Prophet.

Qiyäs in language is the verbal noun of qäsa which has a multitude of meanings: it means "to feel hungry," "to measure the depth of a wound," "to pass somebody else in a race," and finally "to deduct by analogy something from

- Ibid., p. 51. For more details on Ibn Hazm as a polemicist, see Chejne, op. cit., Chapter III, pp. 46-55; also Abu Zahrah, op. cit., pp. 205-371; also Ibrahim, op. cit., pp. 155-179.

5 Ibn Hazm, Ibn Hazm Al-Usul wa-al-Furu , edit. by M.A. al- Iraqi, S. Abu Wafiyah and I. Hilal, first edition (Cairo, 1978), pp. 42-43 of the introduction.

6 Ibrahim, op. cit., p. 180.

7 Chejne, op. cit., pp. 2-3.

8 For more details on Zahirism, see Shorter Encyclopedia of Islam (SEI), edited by H.A.R. Gibb and J.H. Kramers, (Leiden, Brill, 1953), pp. 226-7; also Abu Zahrah, op. cit., pp. 260-282; and for some views on the Zahirite doctrine in relation to analogy, see Chejne, op. cit., pp. 43-46. 
another similar thing."9 It is clear that this last meaning of the word is the one that has a direct bearing on this paper. However, the use of the word as a logical term seems to be absent among the Arabs before they were exposed to Greek philosophy and logic. It was perhaps after the Muslims came into contact with Greek logic, in the second century of the Islamic era, that they became aware of using the term in its logical meaning.

It was during the second century of the Muslim calendar that the term qiyás gained solid ground and was widely applied and used by its advocates in the juridico-theological field as well as in the field of language and grammar.10 Here the paper shall be confined to the use of the term and its development in the juridical-theological field. For the advocates of analogy, applying human criteria in the juridico-theological field was a matter of necessity; they claim that the death of the Prophet Muhammad has deprived the Islamic community of the means of obtaining revelations to serve as a guide in the ever-changing political, social, economic, and religious matters of the Islamic community. At first, they argue that the Qur'an and the Prophetic traditions as well as the consensus of the companions of the Prophet served well as guides for the Islamic community. However, the expansion of the Islamic community under the first orthodox Caliphs, the growing interest in theological and juridical speculation, and the new intellectual and material world brought questions previously unknown. Direct and explicit answers could be found neither in the Qur'an nor in the Prophetic traditions. Under these circumstances, they believe, legalists were forced to apply human criteria, such as qiyäs to arrive at decisions that would meet the needs created under these new circumstances."

It is generally believed that al-Shafi'i (767-820), the founder of one of the four Sunni rites (madhhabs), was probably the first to give an outline of the roots of the theological and juridical system of Islam (usul al-fiqh): the Qur'an, the Prophetic traditions (Sunnah), and the consensus of the companions of the Prophet (ijma-`). For his "qiyās is used in cases which are not dealth with by either the Qur'an or Sunnah or ijma-‘." For al-Shafi' $i$ it seems that qiyās and personal inquiry (ijtihäd) are two terms used for the same idea.12 So with al-Shafi ' $i$, analogical deduction became the fourth most widely recognized source of authoritative support of religious beliefs, practices, and decisions among the orthodox Muslims.

9 See for example al-Mu jam al-Wasit, Vol. 2, (Majma al-Lughah al- Arabiyah, Cairo, 1961), p. 775 under qayasa.

10 For the use of qiyás in the field of language and grammar, see Sa id al-Afghani, Fi Usul al-Nahw, (Damascus, 1957), second edition, a chapter on qiyäs, pp. 67-120.

1 See Short. Encyclopedia of Islam (SEI), under kiyas, p. 266.

12 Al-Shafi i Muhammad ibn Idris, al-Risalah, edited by Ahmad Shakir, (Mustafa al-Babi al-Halabi, Cairo, 1940), p. 663. 
Thus, analogical deduction (qiyäs) was simply defined as the way a belief, practice, or legal decision gains official credence and support on the grounds that it is similar to a practice, belief, or decision clearly embodied in the Qur'an, Prophetic traditions (Sunnah), or consensus (ijma- ${ }^{c}$ ). It seems clear that before analogical deduction was officially recognized, Muslim interpreters of the religious law (Shari' $a h$ ) had exercised personal opinion (ra'y) in reaching legal decisions. Perhaps it was in an attempt to curb the widespread use of personal opinion in a delicate area of religion that analogy came into being as a more acceptable alternative.

It is worth mentioning that during and after the second century of the Muslim era the use of human criteria in matters of law was widely pursued and enlarge. This resulted in applying new methods in reaching legal decisions, and new terms such as precaution (iḥtiyät), preference (istiḩsän), imitation (taqlidd), and causation ( $\mathrm{ta}^{\text {' }} \mathrm{lil}$ ) came into use..$^{13}$ All these methods were termed "human criteria" as opposed to the traditional methods which confined the basis of religious law only to the Qur'an, the Prophetic traditions (sunnah), and the consensus of the companions of the Prophet (ijmá $\dot{a}^{c}$ ).

The use of this human criteria, however, was full of controversy from the very beginning. Muslim theologians debated earnestly and almost continuously the extent and range of its application. In the case of analogy (qiyäs) some argued that it should be restricted to the area of "material similarity"; others advocated its use also in the not-so-well-defined area of similarity in motive or cause. ${ }^{14}$ In spite of its obvious shortcomings in purporting to achieve a uniform consensus, it is generally believed by the advocates of analogy that it was one way of maintaining the progressive development of the Islamic community in conformity with the religious sanctification needed. On the other hand, the advocates of Zähirism considered it as invalid and corrupting the purity of the religious law.

From the outset, however, many theologians were alerted against the shortcomings of applying analogy in matters of religious law. They became aware of the misgivings of the analogists who exaggerated its use to a degree that they falsified some traditions, attributing them to the Prophet in order to prove the validity of analogy. Moreover, they began to misinterpret the meanings of some of the Qur'anic verses if their original meanings were contrary to their analogical deduction.15 Al-Bukhari (810-870) himself a Shafi'ite was aware of the invalidity of using human criteria in matters of religious law;

13 For definition of these terms, see SEI, pp. 184-186, pp. 562-4; see also Abu Zahrah, op. cit., pp. 394-439; also Chejne, op. cit., Chapter VI.

14 Ibn Hazm will discuss this matter, see note 27.

15 Ibn Hazm, Mulakhkhas Ibtal al-Qiyas wa-al-Ra'y wa-al-Istihasan wa-al-Taqlid wa-alRa'lil, edited by al-Afghani, second edition, (Beirut, 1969), pp. 4-5 of the introduction. 
he included in his collection of the Prophetic traditions a chapter entitled "That one must adhere to the Qur'an and the Sunnah." Part seven of this chapter translates as follows: "Traditions relative to the disapproval of ra'y and qiyás." 16 Al-Darimi (d. 869) also collected in his Sunnah a number of Prophetic traditions disapproving the use of personal opinion and analogy (Introducting chapters 16,21$) \cdot{ }^{17}$ Ibn Qutaybah (828-889) was also aware of the misgivings of the analogists; he mentioned their long and boring disputations and singled out some of what he considered ridiculous and strange sayings..$^{18}$

Finally, it is worth mentioning that there might be a psychological factor to the reaction that took place against the advocates of analogy, and consequently, that created the right atmoshpere for the birth of the Zahirite doctrine. For during the early Abbasid period, in the late eight and early ninth centuries, the Abbasid Caliphs encouraged the advocates of analogy and appointed them as chief judges as was the case with Abu Youssef (d. 798) who was appointed by the Abbasid Calif, al-Rashid (785-809), as the Chief Judge in Baghdäd. ${ }^{19}$

\section{Ibn Hazm's approach and methods to his rejection and refutation of analogy.}

Two centuries after its foundation in the East, Ibn Hazm became the most articulate and the most eloquent advocate of Zahirism in Muslim Spain. Within the framework of this doctrine he waged a fierce and ceaseless war against the advocates of human criteria in matters of religious law. He wrote profusely refuting them, mainly in his Ihkam, Fișal, Muhalla, Nubadh, Ibtal, and the Talkhis; in his Ihkam alone about 448 pages are devoted to this refutation. ${ }^{20}$ The following discussion is an attempt to elaborate on Ibn Hazm's rejection and refutation of analogy (qiyäs) - his approach, the basis of his rejection and examples of his refutation. Due to the wealth of information that Ibn Hazm provides under this topic only a sampling is possible here; reference is to be made when necessary for more details and examples.

In his religious writing and discussions Ibn Hazm depends on the texts as well as the rational principles which are determined by the self-evident truth

16 Al-Bakhari, Muhammad ibn Isma il, Sahih al-Bukhari, Vol. IX, (Kitab al-Sha b, Cairo, 1958), p. 123.

17 Al-Darimi, Abd Allah ibn Abd al-Rahman, Sunan al-Darimi, Vol. 1, (Dar Ihya' alSunnah al-Nabawiyyah), pp. 67-72.

18 Ibn Qutaybah, Ta'wil Mikhtalaf al-Hadity, (Cairo, 1326 A.H.), pp. 62-84; also quoted in Ibn Hazm, Mulakhkhas, op. cit., pp. 4-5 of the introduction. 
of the intellect. For this he refutes from the outset all the theories that employ human criteria, emphasizing that God's revelations are all clear, self-proven, and exoteric with no hidden or esoteric meanings. ${ }^{21}$ It is a general rule for Ibn Hazm to follow the way of disputation in arriving at his demonstrations and proofs. He begins by singling out his opponents' evidences one by one. Then he proceeds to discuss them, revealing their invalidity, mentioning proofs that would support and confirm his claims on the one hand and renders as invalid his opponents' claims on the other hand. In the second stage Ibn Hazm moves to nullify his opponents' claims from within, showing their invalidity and contradictions. ${ }^{22}$

Ibn Hazm's approach to his refutation of human criteria follows a fixed pattern. In the case of analogy (qiyäs) he starts by mentioning the century when it first came into existence; the second century of the Muslim era is the time that Ibn Hazm suggests for the appearance of analogy. He mantains that analogy is an innovation that came into existence during the second century A.H. (the year of the Hijrah), but it became widespread and well-established in the third century A.H. ${ }^{23}$ There is, however, some disagreement concerning this point. al-Dhahabi (d. 1348) wrote on the margin of Ibn Hazm's Mulakhkhas, which he copied, saying that analogy was used in the time of the companions of the Prophet; that is to say the first century of the Islamic era. ${ }^{24}$ The modern scholar Abu Zahrah seems also to disagree with Ibn Hazm on this point; he maintains that analogy went side by side with personal inquiry (ijtihad) which was in the first century of the Hijrah. ${ }^{25}$ No matter what the case may be, Ibn Hazm will consider the refutation of this claim within the framework of refuting the analogists. He maintains that using analogy in matters of religion was an innovation of a later generation of jurists; it did not exist in the days of the Prophet and his companions and their early followers. ${ }^{26}$

The second step in Ibn Hazm's approach to the subject is to consider the definition and meaning of analogy according to its advocates and their reasons for applying it in matters of religion. To them the justification for using analogy rests on their claim that there are problems and occurrences that take place without having direct mention to their legal decisions in the Qur'an, the Prophetic traditions, or the consensus of the Prophet's companions. For this reason,

21 Ibn Hazm, Ali ibn Ahmad, Al-Fisal fi al-Milal wa-al-Ahwa' wa-al-Nihal, Vol. II, (Makatabat al-Muthanna, Baghdad, and Mu'ssasat al-Khanji, Cairo, 1321 A.H.), p. 111.

22 Abu Zahrah, op. cit., pp. 182-183.

23 Ibn Hazm, Mulakhkhas, p. 5; also his al-Ihkam fi Usul al-Ahkam, edited by Ahmad Shakir, (Cairo, 1968), p. 1026.

24 Ibn Hazm, Mulakhkhas, p. 5.

25 Abu Zahrah, op. cit., p. 411.

26 Ibn Hazm, Ihkam, p. 929. 
they claim, they look for problems and occurrences in the Qur'an and the Prophetic traditions which resemble these new problems and then apply the legal decision of the former to the latter. For them, Ibn Hazm states, analogy is passing a judgment upon a given problem which has no basis in the sacred texts, or the consensus, like the judgment passed by a direct text upon a similar problem. The advocates of analogy justify passing the same judgment upon the new problem on the basis that the two problems agree on the reason (motive) for which the judgment was passed in the original problem. Ibn Hazm adds that some Hanafites and Malikites justify passing the same judgment even though the new problem resembles only in part the original problem with no need for a complete and full resemblance between the two cases. ${ }^{27}$

In his initial approach to his refutation of analogy, Ibn Hazm quotes the legalist Abu Hanifah who is reported to have said, "It is preferable to adhere to a broken or weak tradition (al-khabar al-mursal wa-al-da'if) than to analogy." ${ }^{28} \mathrm{Ibn}$ Hazm, then, proceeds in his refutation of the very definition that the analogists provided. They say they use analogy to pass a judgment upon a problem "which is not dealt with in a direct and explicit text." To Ibn Hazm this is not true because everything in religion is represented by a direct text. He adds that even on the assumption that there really exists a problem, a judgment cannot be made upon it on the basis of another problem, because that would be passing a claim without having solid proof of it. ${ }^{29}$

The next stage of Ibn Hazm's approach to the subject is his discussion of the three kinds of analogy used by its advocates. First, there is what they call the most similar and impelling (al-ashbah wa-al-awla) which they explain as "if a certain judgment was passed upon a given problem, then a second given problem is more deserving of that judgment." An example of this is found in the saying of al-Shafi î's followers: "If expiation is required for both unintentionally killing and for unintentionally telling a lie, then the intentionally killing and the intentionally lying are more deserving of expiation than the first situation. Second, there is a similar situation (mithl), an example of which is found in the saying of Abu Hanifah and Malik who say that if expiation is required for he who intentionally had sexual intercourse while fasting in any day of the fasting month (Ramadan) then the same expiation is required of the one who breaks fasting by intentionally eating.' Another example is found in al-Shafi'i's saying that 'if it is obligatory to wash a vessel seven times after it has been used by a dog, then the same would be required if used by a pig.' The third kind of analogy is the least similar (al-adna) which is found

27 Ibid., p. 929; also Ibn Hazm. Malakhkhas, p. 5.

28 Ibid., p. 929; also quoted in Chejne, op. cit., p. 126.

29 Ibn Hazm. Mulakhkhas. p. 5. 
in Abu Hanifah's saying that if urine nullifies the ablution, then bleeding does so; or if touching the penis nullifies ablution, so does touching the backside." ${ }^{30}$

In the following stage of his approach, Ibn Hazm cites some Qur'anic verses which the analogists single out in support and as proof of the validity of their claims. Of course, Ibn Hazm proceeds to refute their claims using the same verses and adding others. The analogists, in support of their claims, quote the following part of the Qur'anic verse, “. . . say not 'Fie' unto them (your parents). .." ${ }^{31}$ The analogists claim that according to the direct and exoteric meaning of the verse, Muslims were only ordered not to say 'Fie,' but by analogical deduction they were ordered not to beat them, not to kill them, and not to do any harm to them. To this Ibn Hazm replies that though the word 'Fie' does not include the meaning of beating or killing, it is understood that this includes not beating or killing them as well. This is understood not by analogical deduction but by taking into consideration the whole context in which the words "say not Fie" have occurred. Ibn Hazm cites the whole context that reads, "Thy Lord hath decreed that ye worship none save Him and (that ye show) kindness to parents. If one of them or both of them attain to old age with thee, say not 'Fie' unto them nor repulse them, but speak unto them a gracious word. And lower unto them the wing of submission through mercy, and say: My Lord! Have mercy on them both as they did care for me when I was little." ${ }^{32}$ After citing the whole context, Ibn Hazm comments that it is within the framework of the whole context that Muslims were ordered to be good and kind to their parents in all forms and aspects of kindness and goodness, while on the other hand they were ordered not to do any harm to them no matter in what form it was done. Thus Ibn Hazm maintains that the meanings the analogists claimed they understood through analogical deduction, are, in fact, directly understood through the esoteric meanings of the words included in the whole context; so there is no need to deduct any meaning by analogy. Ibn Hazm concludes this discussion by attacking the analogists saying that it is their habit to cut off parts of the Qur'anic verses from their whole context to prove falsely their own point of view. ${ }^{33}$

In another example, the advocates of analogy quote in support of their system the verse that reads "And who so doth good an atom's weight will see it then (in the Hereafter)." ${ }^{34}$ They argue that though only an atom's weight of good is mentioned, by analogical deduction it is understood that any other quanti-

30 Ibn Hazm, Ihkam, p. 930; quoted also in Chejne, op. cit., p. 126.

31 Quran, 17:23. (Muhammad M. Pickthall translation, Muslim World League, Rabita, Mecca, 1977).

32 Ibid., 17:23-24.

33 Ibn Hazm, Ihkam, pp. 931-33; see also his Mulakhkhas, pp. 23, 29-30.

34 Qurian, 99:7. 
ty of good is included. To this Ibn Hazm replies that it is understood that any other quantity of good is to be accounted for not by applying analogy but rather through other verses of the Qur'an, the direct and exoteric meanings of which indicate what the analogists understood through analogical deduction. Ibn Hazm quotes the following verses to support his view: "This day is each soul requited that which it hath earned; no wrong is done this day. Lo! Allah is swift at reckoning;" 35 "And the Book is placed and thou seest the guilty fearful of that which is therein, and they say, "What kind of a Book is this that leaveth not a small thing nor a great thing but hath counted it!' And they find all that they did confronting them and thy Lord wrongeth no one." ${ }^{36}$

In a third example the advocated of analogy claim that in the Qur'an only fearing a fall to poverty is mentioned as unacceptable reason for killing our children, but by analogical deduction we understand that no other reason is acceptable for killing our children. They quote the verse that says, "Slay not your children, fearing a fall to poverty. We shall provide for them and for you! The slaying of them is a great $\sin .{ }^{37}$ to Ibn Hazm the killing of our children is a great $\sin$, no matter what the reason is, not by virtue of applying analogy but rather by the direct and exoteric meanings embodied in other verses of the Qur'an, such as: "They are losers who besottedly have slain their children without knowledge. . "; $;{ }^{38}$ and "And slay not the life which Allah hath forbidden save with right. .." ${ }^{39}$

Judging from the way Ibn Hazm has approached the refutation of the two last examples, one might conclude that for him the Qur'an represents a whole unity; that is to say that Ibn Hazm believes that the whole verses of the Qur'an are supplementary to each other. So when there is a verse that does not convey a direct meaning concerning a given matter there should be another verse or verses that supplement and directly clarify what was not directly understood in another verse. This also leads one to conclude that Ibn Hazm was very knowledgeable and aware of every single verse in the Qur'an. Moreover, for him the Prophetic traditions (sunnah) are supposed to serve as supplementary tools for the Qur'an, so whenever there is no direct mention to a given problem in the Qur'an it would be found in the Prophetic traditions. ${ }^{40}$

In other passages of his refutations of analogy, Ibn Hazm displays a profound knowledge of the Arabic language which he employs as a method in

\footnotetext{
35 Ibid., 40:17.

36 Ibid., 18:49; see also Ibn Hazm, Mulakhkhas, pp. 23, 30.

37 Quran 17:31.

38 Ibid., 6:140.

39 Ibid., 17:33; see Ibn Hazm, Mulakhkhas, pp. 24, 30; also his Ihkam, p. 937.

40 See, for example, Ibn Hazm's Ihkam, p. 937 and after.
} 
refuting his opponents. Judging from the way he approaches some problems in his refutations, Ibn Hazm seems to be revealing the shortcomings of his opponents in understanding the Arabic language in which the Qur'anic verses and the Prophetic traditions were expressed and written. A good example for this method is his refutation to the analogists in their claim that the direct prohibition for eating pork is related only to swine flesh (lahm khinzir) according to the Qur'anic verse. By analogical deduction it is known that eating of its fat is prohibited too; therefore, the flesh and fat of the sow is prohibited. To this Ibn Hazm replies that the swine's fat was prohibited not by analogical deduction, but rather because the context in which the prohibition occurred had a direct bearing upon the prohibition of the swine's fat and the sow's flesh and its fat. Ibn Hazm argues that God says in the same verse that "it is foul (filth)" and the suffix pronoun (in Arabic) which is represented in English by "it" is related to the closest noun which is the swine itself (khinzir) and not to its flesh only (lahm). Because the swine itself is foul (filth) necessarily and logically everything that comes from it is filthy and unclean. The Qur'anic verse which Ibn Hazm quotes in full reads as follows, "Say: I find not in that which is revealed unto me ought prohibited to an eater that he eat thereof except it be carrion, or blood poured forth, or swine flesh, for it is verily foul or the abomination which was immolated to the name of other than Allah. But who so is compelled (thereto), neither craving nor transgressing (for him). Lo! your Lord is forgiving, merciful." ${ }^{\prime 1}$ Ibn Hazm also reminds us that Muslims were asked to avoid unclean and filthy things in several verses of the Qur'an; he cites some of them. As for the prohibition related to the sow, Ibn Hazm maintains that this prohibition is included directly in the word swine, because the Arabic word used for swine (khinzir) is a generic noun standing for the whole species which includes both male and female. ${ }^{42}$

In other passages Ibn Hazm continues to refute the advocates of analogy by revealing their misinterpretation of the meanings of the words, and their shortcomings in understanding the language. The analogists used the following verse to support their claims in using analogy: “. . so learn a lesson, O ye who have eyes!" The advocates of analogy interpreted the Arabic imperative

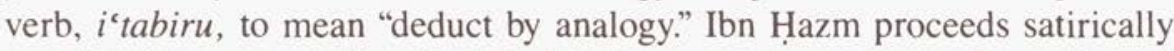
to refute them, reminding that if what they wrongly understood was the real meaning of the verb, then that would imply an order for Muslims to destroy their own houses as the disbelievers did, since this order embodied in the

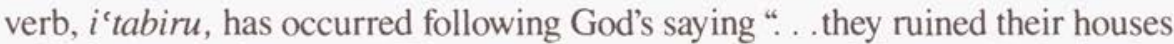
with their own hands. .." The complete verse reads as follows: "He it is who

\footnotetext{
${ }^{41}$ Quran 6:146.
}

42 See Ibn Hazm, Mulahkhkas, pp. 24, 31-32; also his Ihkam, pp. 961-63. 
hath caused those of the people of the scripture who disbelieved go forth, while they deemed that their strongholds would protect them from Allah. But Allah reached them from a place whereof they recked not, and cast terror in their hearts so that they ruined their houses with their own hands and the hands of the believers, so learn a lesson, O ye who have eyes!" 43 Ibn Hazm cites several other examples from the Qur'an where the same word, $i^{\text {'tabara, }}$ or a derivation from it is used only to mean "to learn a lesson." This leads Ibn Hazm to consider a discussion of some aspects of the language in an attempt to prove the word "analogy" in the sense that the analogists used it later on did not exist either in pre-Islamic Arabic language or in the Qur'an and the early Islamic period. ${ }^{44}$

In his attempt to refute the analogists and to prove that analogical deduction did not exist and was not recognized during the lifetime of the Prophet and his companions, Ibn Hazm devotes a considerable number of pages to this question. He starts by mentioning the claims of some analogists that there was a consensus among the companions of the Prophet in using analogy. To Ibn Hazm this is a mere aggressive and ugly claim that has no basis in reality. He admits that they sometimes passed legal decisions using their personal opinion ( $r a^{\prime} y$ ), but never by using analogical deduction. He argues that none of them is known to have passed a legal decision according to analogy in the life of the Prophet. If analogy was something valid, the Prophet would have not neglected it, and he would have explained it-when and how it should be used and in what situations and circumstances it should be used. Since he mentioned nothing about analogy, it is proven to be invalid, Ibn Hazm argues. ${ }^{45}$

In connection with his refutation and rejection of the existence of analogy in the time of the Prophet's companions, Ibn Hazm recognizes the only two sayings that have direct bearing on this question. The first is a letter attributed to the second orthodox Caliph 'Umar ibn al-Khattab (634-44) which is believed to have been written by him to his governor Abu Musa al-Ash'ari (d. 665). The letter translates: "Know the similarities between matters and use analogical deduction, then choose what is closer to the right and more acceptable by God, and use it to pass legal judgments." The second saying is attributed to the fourth orthodox Caliph 'Ali (656-661) in which he says: "For he who knows the prohibited and the permissible, analogy is the cure for the world (problems)." Ibn Hazm refutes these two sayings by simply rejecting the authenticity of them on the basis that some of the persons mentioned in the chain of the transmitters are either unknown or their authority unrecognized. ${ }^{46}$

43 Qurian 59:2.

4 See Ibn Hazm, Mulakhkhas, pp. 23-28; also his Ihkam, pp. 947-951.

45 Ibid., pp. 5-6; Ibid., pp. 979-98].

46 Ibid., pp. 5-7; Ibid., pp. 102-105. 
In their attempt to prove that analogy was used and practiced during the Prophet's companions time, the analogists argue that the consensus of the Islamic community to choose Abu Bakr (632-34) as the successor of the Prophet was done on the basis of analogical deduction; because during the Prophet's sickness which preceded his death he chose Abu Bakr to replace him in leading Muslims in their prayers. To Ibn Hazm this is false and unture; he proceeds to refute in length their claims, discussing the conditions that qualify an individual to lead the prayers, on the one hand, and the conditions that are required to qualify a person to be a religious and political leader of the Islamic community on the other hand. Ibn Hazm delves deeply into legal questions concerning this matter, concluding that the conditions required in leading the prayers are very different from those required for succession. For Ibn Hazm, Abu Bakr was chosen to succeed the Prophet because he met the many qualifications required and not merely because the Prophet happened to choose him for leading the prayers during his sickness. ${ }^{47}$

In such a manner Ibn Hazm proceeds with his refutations of the analogists' claims that the companions of the Prophet practiced analogical deduction. He devotes ample space to this in his Ihkam. ${ }^{48} \mathrm{His}$ approach to this question is almost identical to what we have already seen. He starts by citing the analogists' claims and examples, then he proceeds to refute them on two bases: he either shows that the analogists' claims are lies and unauthenticated or he shows that they are not based on analogical deduction, but rather they represent misinterpretation on the part of the analogists. Ibn Hazm concludes then that the Prophet's companions did not know or practice analogy; it was an innovation that was developed later in the second century of the Islamic era and became widespread in the following century. ${ }^{49}$

In his insistence to prove that analogical deduction did not exist during the early Islamic period, Ibn Hazm carries his discussion concerning this question a step further. He cites examples attributed to some of the Prophet's companions, their immediate followers, and well-known Muslim legalists such as 'Umar (d. 644), Ibn Umar (d. 692), Ibn Mas'üd (d. 652), Mu'ädh ibn Jabal (d. 639), Ibn Abbas (d. 687), Malik ibn Anas (d. 795), Abu Hanifah (d. 767), and others. These examples are direct and clear and prove a rejection of analogy. Due to the exhaustive nature of these examples only a sampling is attempted in the following paragraphs.

Among these examples Ibn Hazm cites the words of Abu Hurayrah who addressing Ibn Abbas said: "In the presence of a tradition attributed to the

47 Ibid., p. 36; Ibid., pp. 982-989.

48 Ibn Hazm, Ihkam, pp. 1002-1026.

49 Ibid., p. 1026. 
Messenger of God do not try to apply it to a similar situation." On this Ibn Hazm comments that this is a direct word from Abu Hurayrah in rejecting analogy. ${ }^{50}$ In another example Ibn Hazm cites the answer of Ibn Mas'üd to a man and a woman who came to him inquiring about a legal problem. His answer confirmed that God had clarified everything in His Scripture and that what does not confirm what was revealed by God is rejected as invalid. "This is a rejection of analogy," Ibn Hazm states. ${ }^{51}$ In a third example Ibn Hazm quotes Malik who is reported to have said that the Prophet himself used to say, "I do not know' when he did not receive an answer to a question through revelation. He used to await God's answer to this kind of question. On this Ibn Hazm comments: "The Messenger of God himself did not answer legal questions according to analogy or any other human criteria; he would wait for revelation. It is a big sin to do what the Prophet did not permit himself to do!"'52

Another method pursued by Ibn Hazm in his refutation is singling out specific examples or sayings of the analogists, then refuting them using his dialectical ability in disputation. Again only a few examples are possible here. In one passage the analogists argue that analogy is passing a judgment upon something absent $\left(g h a^{\prime} i b\right)$ from the canonical law according to something present (hädir) in it. Ibn Hazm replies that this is a false commotion because they talk about the presence and the absence in canonical law, while every Muslim knows that there is nothing in religion that is absent from the knowledge of Muslims. It is for the purpose of clarifying and teaching the people their needed religion that God sent his Messenger. God says, "With clear proof and writing We have revealed unto thee the remembrance that thou mayst explain to mankind that which hath been revealed for them and that haply they may reflect." 53 Ibn Hazm argues that there are only two possibilities in looking at the matter here: either that the Messenger of God did not explain and clarify God's revelation to the Muslims, and whoever says this is an infidel according to the consensus of the whole Muslim community; or that the Prophet had explained and clarified to Muslims all the aspects of their religion as he was ordered and instructed by God, and there is no doubt that he did so. This being the case, where and what is the absence in religion that the analogists talk about? ${ }^{54}$ In another passage Ibn Hazm quotes the analogist al-Karkhi (d. 815), who,

50 Ibid., p. 1068.

51 Ibid., p. 1071.

52 Ibid., p. 1071. For more examples see Ibid., pp. 1068-1081; see also Ibn Hazm's Mulakhkhas, pp. 68-71. It is worth mentioning that Ibn Hazm's quotations are cited with their full chain of transmitters.

54 Ibn Hazm, Ihkam, pp. 1026-1027. 
in preferring one form of analogical deduction to another used to say, "It is the most accurate of the two." Ibn Hazm argues that if there is a form of analogy that neglects another, renders it invalid, or opposes it, then this is in itself a proof that the whole concept is invalid; a right and valid thing does not contradict itself, nor some of it render another part as invalid. Things cannot be right and wrong at the same time, and if something renders a part of itself as invalid then the whole thing is invalid in itself. ${ }^{55}$

In a third passage Ibn Hazm states that God had legislated in his Revealed Book that blood-money and expiation are required in unitentionally killing a believer. The analogists required the same blood-money and expiation in case a believer unintentionally kills a Dhimmi ${ }^{56}$ they did so though this is not mentioned in the Qur'anic verse. Then the analogists differed among themselves, Ibn Hazm argues. One group required the expiation in an intentional killing following the example of the unintentional killing; another group did not require this expiation. Ibn Hazm argues that the contradiction among the first group was greater because they required expiation for mistakenly killing wild game (Sayd) during the pilgrimage period following the example of killing it intentionally, while they did not require expiation in case of an intentional killing of a believer as they did in case of mistakenly killing him. Ibn Hazm states that the analogists interpreted this way in spite of the fact that they were aware of God's saying, “. . . and there is no sin for you in the mistakes that ye made unintentionally, but what your hearts purpose (that will be a $\sin$ for you) $\ldots{ }^{{ }_{57}}$ and of His Messenger's saying, "My nation is not responsible for what it does mistakenly, forgetfully, or what it is forced to do." ${ }^{58}$ So judging by these two texts no one is to be held responsible for unintentional wrongdoing except that which the texts point out as fulfulling the necessary expiation in case of mistakenly killing a believer. ${ }^{59}$ Considering the discussion in the foregoing account, one can observe that Ibn Hazm wants to prove that the analogists base some of their judgments without having solid ground in the holy texts; or perhaps he wants to prove that they misinterpret these texts. It is clear also that Ibn Hazm attempts to prove that the advocates of analogy display their differences, contradictions, and inconsistencies.

Revealing the analogists' contradictions and inconsistencies is another method through which Ibn Hazm approaches his refutation and rejection of analogy. He states that the analogists sometimes call it extracting (istinbat), then he

\footnotetext{
55 Ibid., pp. $760-761$.

56 A Dhimmi is a free non-Muslim subject under Muslim rule.

57 Quran, 33:5.

58 Ibn Majah, Sunnan, ed. Abd al-Baqi, (Cairo, 1952) vol. I, bab al-talaq. 16. no. 2043. p. 609 .

59 Ibn Hazm. Ihkam, pp. 923-24.
} 
proceeds to argue that extracting is something different from analogy. This he also refutes on the basis of the Qur'anic verses. ${ }^{60}$ Concerning the analogists' inconsistency Ibn Hazm says that they make expiation binding for intentionally eating on a fasting day during Ramadan following the example of breaking a fast by intentionally having sexual intercourse. They do not, on the other hand, apply the same analogical deduction in the case of intentionally thwarting a prayer. ${ }^{61}$ In another example the analogists require that the same punishment should be inflicted upon a sodomite as it is for an adulterer. On the other hand, they did not require that the same punishment should be inflicted upon he who had sexual intercourse with an animal as it is for an adulterer, while in both cases a prohibited form of intercourse was committed. ${ }^{62}$

Throughout this discussion of the different methods used by Ibn Hazm in his refutation of the analogists there runs a visible thread that makes it possible to summarize his proofs, done so in the following paragraphs.

The first proof is based on Ibn Hazm's belief that God revealed the canonical laws: what He ordered Muslims to do is an obligation that they must carry out; what He prohibited is unlawful and should be avoided; and what $\mathrm{He}$ did not prohibit is lawfully permissible. The holy texts have made clear everything that falls under the two first categories; the rest are considered legally permissible. On the one hand, he who, beyond that, imposes an obligation on the basis of analogy or any other human criteria is, according to Ibn Hazm, an innovator who brings about something that God did not permit: on the other hand, he who prohibits something without the solid ground of a text support is bringing about something that God did not mean. ${ }^{63}$

The second proof that there is no analogical deduction is that according to its advocates, it is needed where no direct text exists and not where one does exist. Those who claim that the sacred texts did not include and cover everything in religion are simply contradicting God's words, “. . This day have I perfected your religion for you and completed My favor unto you, and have chosen for you as religion al-Islam. . ." 64 This verse among other verses ${ }^{65}$ that Ibn Hazm quotes are for him clear evidence that the texts have included everything, so there is no need for analogical deduction. ${ }^{66}$

The third proof is that deduction by analogy where there is no direct text

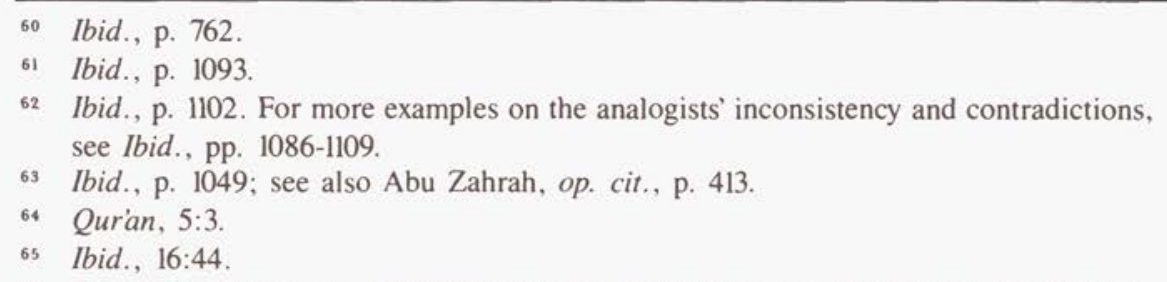

66 Ibn Hazm, Ihkam, pp. 1049-1050; also his Mulakhkhas, pp. 45-46; also Abu Zahrah, op. cit., p. 413. 
is based upon the existence of a common motive or characteristic which is considered the pretext of judging the new case according to the original. This motive or characteristic has to have evidence to point to it; if this evidence is the text itself then the judgment passed upon the case under question is taken from it and this in turn is not reasoning by analogy. If the evidence is not taken from a text then how was it known? Ibn Hazm argues that the analogists' judgment in this case has no solid basis and as a result is invalid. ${ }^{67}$

The fourth proof is based on the fact that the Prophet asked the believers to leave what God and the Prophet have left to its origin when there is no given text. ${ }^{68}$ For this reason, Ibn Hazm argues, that on the assumption that there is no direct text for a given question, human beings are not allowed to legislate passing a permission or a prohibition upon such a question because that would mean that they are altering God's legislation. ${ }^{69}$

Finally, there are several Qur'anic verses that stand as direct evidence against analogical deduction. Ibn Hazm cites examples of these verses throughout his lengthy discussions. Some of these examples have been mentioned in different passages of this paper. Some additional examples follow: "Lo! We reveal unto thee the Scripture with the truth, that thou mayst judge between mankind by that which Allah showeth thee. And be not thou a pleader for the treacherous."; ${ }^{70}$ "...We have neglected nothing in the book (of our decrees). Then unto their Lord they will be gathered."; "(O man), follow not that whereof thou hast no knowledge. Lo! the hearing and the sight and the heart-of each of these it will be asked."; ${ }^{72}$ "Even as We have sent unto you a messenger from among you, who reciteth unto you Our revelations and causeth you to grow, and teacheth you the Scripture and wisdom and teacheth you that which ye knew not." ${ }^{33}$ For Ibn Hazm these Qur'anic verses among others stand as evidence that in religion we do not know anything except what God has taught us through his Scriptures and Messengers; analogy then is something invalid in religious matters because it does not come from God. ${ }^{74}$

67 Ibid., pp. 1050-52; Ibid., pp. 413-414.

68 Ibn Hazm quotes a Prophetic tradition that expresses this meaning; see Muslim, Sahih, edited by Abd al-Baqi (Cairo, 1955), Kitab al-Hajj, bab 73, no. 412, p. 975. Ibn Hazm, Ihkam, pp. 1052-53; also his Mulakhkhas, pp. 38-39; see also Abu Zahrah, op. cit., p. 414.

Quran, 4:105.

Ibid., 6:38.

Ibid., 17:36.

Ibid., 2:151.

4 Ibn Hazm, Ihkam, pp. 1055-56. For more details on his proofs see Ibid., pp. 1049-81; also see Abu Zahrah, op. cit., pp. 411-422; also Ibrahim, op. cit., pp. 190-195. 


\section{Conclusion}

The foregoing account has made it clear that Ibn Hazm was a fierce opponent of the advocates of human criteria in matters of religion for him analogical deduction is a "claim without proof" ( $d a$ wa bila burhan), a phrase that he uses frequently in refuting the advocates of human criteria in the field of religion. He viewed analogical deduction as an innovation that should be set aside; instead, legal decisions should be based upon the Qur'an, the proven Prophetic traditions (sunnah), and the consensus (ijma) of the venerable companions of the Prophet as the last resort.

Because the facts discussed in this paper give rise to several questions, only a brief speculation is possible concerning them in this conclusion. The first question can be phrased as follows: What does Ibn Hazm's rejection to human criteria prove? Perhaps it proves in the first place that Ibn Hazm held the Qur'an and the Prophetic Tradition so highly that he insisted to keep them as the sole basis for religious decisions. To him they are comprehensive, selfsufficient, and supplementary to each other. They are valid for finding answers to all questions in all places and times. With the Qur'an and the Sunnah human criteria seems unnecessary. Furthermore, human criteria has its shortcomings, mainly because it corrupts religion and leads to sacrifice of heavenly teachings for humanly innovations. No doubt Ibn Hazm had in mind that any advancement in applying human criteria in matters of religion is going to be achieved at the expense of the true teachings of the religion. It is perhaps the fear that religion might be corrupted and tampered with that led Ibn Hazm to his strong opposition to human criteria. No one in his time was as aware as he was of the common belief among Muslims that the original teachings of Christianity and Judaism have been corrupted and tampered with by the very religious figures of the two religions. This question is among the most important questions that preoccupied Ibn Hazm's mind and about which he wrote profusely. If these assumptions are ture, then it becomes safe to say that Ibn Hazm was a religious reformer who based his reformation upon going back to the fundamental teachings of Oskam at a time when the advocates of human criteria seemed for him to be corrupting and misinterpreting the teachings of the religion.

Other questions raised by this discussion may be put in these words: Was Ibn Hazm's rejection of analogy confined to the field of religion or was it a rejection to the whole concept of analogy? If the answer is that he rejected the whole concept, then the following question is raised: How can the contradiction between his rejection to analogy and his writings in logic be explained when it is based among other things upon analogy? These questions require serious investigation and no simple answer can be given here because, from the outset, it seems that there are conflicting opinions concerning these questions. Al-Afghani, for example, in his introduction to Ibn Hazm's Mulakhkhas argues that Ibn Hazm opposes analogy in religious matters because 
he is a strong believer in logic. ${ }^{75}$ On the other hand, in his study about Ibn Hazm, Professor Chejne after examining the format of Ibn Hazm's Taqrib as compared with the eight books of Aristotle's Organism, concludes that "Ibn Hazm deleted a special treatment of qiyãs and substituted burhan (proof) which corresponds to Aristotle's fourth book. This illustrates his strong opposition to the validity and use of qiyäs (analogy) whether applied to law, theology, or grammar." ${ }^{\prime 6}$ To the charges that he equates the evidence (dalil) with analogy (qiyäs), Ibn Hazm himself protests that his dalil has nothing to do with human criteria, but constitutes the evidence which is contained in the Scriptures. ${ }^{77}$

With this difficult question this paper comes to its conclusion while the echoes of Ibn Hazm's strong arguments and his convincing proofs leave no doubt that he was a man of erudition, a great dialectician, and an outstanding polemicist.

Ibn Hazm, Mulakhkhas, pp. 10-11 of the introduction.

76 Chejne, op cit., p. 175.

77 Ibn Hazm, Ihkam, pp. 676ff. 